Chapter 15

\title{
Soybean Urease: Over a Hundred Years of Knowledge
}

\author{
Rafael Real-Guerra, Fernanda Stanisçuaski and \\ Célia Regina Carlini
}

Additional information is available at the end of the chapter

http://dx.doi.org/10.5772/52106

\section{Introduction}

Ureases are metalloproteins responsible for the one step hydrolysis of urea into ammonia and carbamate [1], the later then rapidly and spontaneously decomposes to form carbon dioxide and a second molecule of ammonia [2]. Plant ureases hold a special place in science history, participating on some important landmarks of biochemistry. For instance, it was by the analysis of Canavalia ensiformis urease crystals that the proteinaceous nature of enzymes could be demonstrated [3], rendering a Chemistry Nobel Prize to James Sumner in 1946. Also by the studies carried out with the same protein it was obtained the first proof that $\mathrm{Ni}^{2+}$ actually exerts a biological role in living organisms [4]. Ureases usually present two $\mathrm{Ni}^{2+}$ in their active site, with a few exceptions reported [5, 6]. However, all this was only possible after Takeuchi's observation that the crude extracts of soybean (Glycine max) seeds present high amounts of urease [7]. In those days, urease had been observed only in microorganisms and in algae, being Takeuchi's finding the first evidence of the presence of ureases in higher plants. The importance of this discovery relays on the fact that it made urease largely available for any researcher on the globe, and many more works on ureases followed, utilizing the soybean seed urease with the objective of understanding enzyme functioning. Soybean urease was also one of the key players on the development of enzymology, with studies on this enzyme leading to hypothesis that were essential to confirm the observations of Michaelis and Menten on the rate of reaction of enzymes and substrates [8].

From those first studies more than one century ago until today, soybean ureases continued to be the focus of researchers around the world, in the fields of genetic, biochemistry and physiology. This review will deal with the many faces of these proteins, trying to summarize the great amount of information gathered over time, and to point the many doors that continue to be opened by the studies with this enzyme. 


\section{Soybean urease - more than one enzyme}

During the course of urease history, there were several reports on the presence of nongenetic isoenzymes for C. ensiformis, which represented different multimeric interconversible forms of the same enzyme. As many as 12 different forms of the protein could be observed, depending on environmental factors such as temperature, $\mathrm{pH}$, salt concentration, reagents, etc [9-13]. Also, multimeric forms of the soybean urease were observed [14, 15]. By the comparison of the purified urease from soybean seeds and a partially purified urease from a soybean shoot cell culture, it was not possible to differentiate them on basis of electrophoretic species, size exclusion chromatography and immunoinhibition, but they seemed to behave differently on a immunoaffinity chromatography, where $100 \%$ of the seed enzyme would be retained in contrast with only $65 \%$ of the culture urease [15]. Although the authors postulated that this behaviour may indicate the existence of two different enzymes, at the time they could not reject the hypothesis of differentially processed forms of the seed enzyme (glycosylated protein, etc).

The next indication of the existence of more than one genetic isoform of soybean urease emerged a few years later, in 1982. After screening a collection of over 6,000 lines of soybean seeds from the United States Department of Agriculture (USDA) Polacco and co-workers were able to identify one urease negative soybean variety (Itachi) [16]. Interestingly, even though no measurable amounts of urease could be detected in the seeds of the Itachi variety, when cells from many parts of the plant were cultured, urease was produced in equivalent amounts to the wild type soybean. Making use of immunoaffinity chromatography with monospecific antibodies that retained $100 \%$ of the soybean seed urease, it was observed that none of the cell culture ureases could be retained completely by the antibodies (70 and $45 \%$ for the wild type and Itachi, respectively). Some differences in the inhibition profile by hydroxyurea were also observed, the ureases from both cultures (wild type and Itachi) being less susceptible than the urease purified from the seeds. All these facts pointed to a similar but still different urease synthesized in cell cultures as compared to the one present in the seeds. However, the authors seemed to battle a little with the idea of a second genetic isoform of urease, considering that the observed "heterogeneity" could be due to a glycosylated seed urease.

More definitive proofs of the existence of a second and distinct isoenzyme appeared when Kerr and co-workers [17] carried out biochemical characterizations of the seed and the leaf ureases, showing that the enzymes differed on several characteristics, such as optimum $\mathrm{pH}$, apparent $K_{\mathrm{m}}$, inhibition profile by hydroxyurea and cross-reactivity against soybean seed urease antibodies. These observations were further extended by Polacco and Winkler [18] who found that the previously observed urease production by the cell cultures of a supposedly urease negative line actually corresponded to the production of a second isoform of urease present in the tested tissues (leaf, callus, seed and cotyledon). The hypothesis of the existence of more than one non-seed isoenzyme, very similar to each other but specific for each tissue, was considered at the time. Since then, this second isoform was denominated 
ubiquitous soybean urease (herein referred as ub-SBU) while the seed isoenzyme would later be denominated embryo-specific urease (herein referred as es-SBU) [19].

The data gathered in these studies set ground for investigations in different fields and to the growing understanding of ureases, mainly in genetics, in the search for definitive answers regarding the diversity of this enzyme.

\section{The discovery of soybean urease genes}

Buttery and Buzzell [14] can be considered the pioneers on genetic studies involving soybean urease. In their work they identified in the soybean seed two variants of urease showing distinct electrophoretical mobility, which they assigned as fast- and slow-moving forms. These forms were later on characterized as the trimeric and hexameric forms of es-SBU, respectively $[15,19]$. In their study, Buttery and Buzzell found the slow-moving form to be recessive, while the fast-moving form was considered dominant, and they concluded that a single locus (named $E u$, after enzyme urease) controlled the expression of these electrophoreticaly variant forms. Many years later, Kloth and Hymowitz [20] advanced the investigation on the two multimeric forms and, by performing a series of crosses between urease null and wild type soybeans, proposed the existence of two codominant alleles, named Eu1- $a$, for the hexamer and Eu1-b, for the trimer. The Eu1 gene, which encodes the es-SBU, was the first urease related gene described for a plant.

Probably the biggest milestone on soybean urease genetics research was the identification of null variants of es-SBU. First obtained by Polacco and co-workers [16], the variety Itachi was found to lack both the es-SBU protein [21] and mRNA [22]. Later on, four more mutants were identified [23], two lacking detectable amounts of es-SBU mRNA, and two producing very low protein levels. One of these later mutants produced a much altered protein. All those mutants were related to the locus Sun (for soybean urease null), and the Sun allele (normal es-SBU) was dominant over the sun allele (null es-SBU activity) [23-25]. The fact that allelic sun mutations affected urease transcript as well as es-SBU structure led to the conclusion that Sun and Eu1 describe the same locus, and that the Eu1-Sun is the single functional es-SBU structural locus. Thus any mutant defective only on es-SBU is considered a Eu1 or class I mutant. [25]. A genomic clone for urease was recovered from a soybean library and it was shown that this urease coding sequence was absent from seed urease-null mutants [22]. This would be confirmed as the first partial sequence obtained for the es-SBU years later.

Mutations obtained from ethyl methyl sulfonate treatment of soybean seeds [23] revealed a new class of mutants. Class II mutants produce normal levels of es-SBU and ub-SBU mRNA and protein, however their enzymatic activity is completely absent [23, 26]. Mutants of this class carry damage in one or both loci Eu2 and Eu3, which are unlinked to each other or to Eu1. Studies on the urease profile during soybean development have shown that maximal synthesis of es-SBU in the developing cotyledon lags the maximal urease activity, suggesting a very slow maturation process of the enzyme in vivo. The facts that es-SBU is a $\mathrm{Ni}^{2+}$ containing enzyme [15] and the presence of $\mathrm{Ni}^{2+}$ is absolutely required for in vivo urease ac- 
tivity $[27,28]$ but not for urease synthesis $[18,21]$ are compatible with the assumption that $\mathrm{Ni}^{2+}$ emplacement into the active site could be a limiting process for urease activation. Holland and Polacco [29] have shown that class II mutants present normal $\mathrm{Ni}^{2+}$ uptake and translocation, thus eliminating the possibility that lack of access to $\mathrm{Ni}^{2+}$ was the reason for the absence of activity of both ureases. These observations pointed to Eu2 and Eu3 having a direct role on enzyme maturation probably by codifying proteins responsible for the $\mathrm{Ni}^{2+}$ emplacement, and that they are common for both es-SBU and ub-SBU [30]. As discussed later, Eu2 and Eu3 were found to encode two different urease accessory proteins, involved in the enzyme maturation process.

After those findings, the remaining question was: is ub-SBU codified by a single gene or are there many tissue specific ureases? This question was clarified when mutants were obtained that presented normal levels of es-SBU activity, but no ub-SBU activity in any tissue. Those mutants were classified as class III mutants. Crosses between Class I and Class III mutants are devoid of ub-SBU even in embryonic tissues. The presence of the protein was detected in all tested tissues of class III mutants despite the lack of urease activity, showing that the lesions affected directly the structural gene of ub-SBU resulting in the production of an inactive protein [26]. The lesions causing this effect were attributed to a new locus named Eu4 [26, 31-33]. This finding demonstrated that the ub-SBU was actually a single protein synthesized in all tissues, and confirmed the existence of two genetic isoforms of soybean urease. A final blow on this question came when Goldraij and co-workers [34] finally obtained and sequenced the cDNA of both isoforms showing that they are very similar, sharing $87 \%$ of identity and $92 \%$ of similarity.

The genomic era brought with it the last pieces of the puzzle. The sequencing of the soybean genome [35] confirmed the presence of the two previously described genes of urease, and also revealed a third one (Glyma08g10850), which is believed to be inactive due to a high number of deleterious mutations. Nevertheless, a residual activity was observed in double mutants, lacking both es-SBU and ub-SBU, and accounted for 2 to $10 \%$ of activity compared to the wild ub-SBU activity. This activity was designated as "background" and it was attributed to microbial commensals in soybean tissues [26, 31, 36]. Alternatively, complementation between the defective Eu4 gene and this third urease-like gene may cause the residual activity [37]. The genome sequencing also brought light over the urease accessory proteins. A single gene for UreG, two for UreF and two for UreD were identified in the soybean genome. Table 1 summarizes the data derived from the soybean genome available at the Phytozome databank [38].

\begin{tabular}{cccccc}
\hline $\begin{array}{c}\text { Phytozome } \\
\text { accession id }\end{array}$ & Gene (locus) & Gene size (bp) & $\begin{array}{c}\text { Protein } \\
\text { codified }\end{array}$ & $\begin{array}{c}\text { Protein size } \\
\text { (aminoacids) }\end{array}$ & References \\
\hline Glyma05g27840 & Eu1 & 7736 & $\begin{array}{c}\text { Embryo-specific } \\
\text { urease }\end{array}$ & 839 & {$[23,33,34]$} \\
\hline Glyma11g37250 & Eu4 & 7287 & $\begin{array}{c}\text { Ubiquitous } \\
\text { urease }\end{array}$ & 837 & {$[23,33,34]$} \\
\hline
\end{tabular}




\begin{tabular}{|c|c|c|c|c|c|}
\hline $\begin{array}{l}\text { Phytozome } \\
\text { accession id }\end{array}$ & Gene (locus) & Gene size (bp) & $\begin{array}{l}\text { Protein } \\
\text { codified }\end{array}$ & $\begin{array}{l}\text { Protein size } \\
\text { (aminoacids) }\end{array}$ & References \\
\hline Glyma08g10850 & Not described & 5849 & $\begin{array}{c}\text { Urease-like } \\
\text { protein }\end{array}$ & 713 & - \\
\hline Glyma02g20690 & Not described & 3473 & $\begin{array}{c}\text { Accessory } \\
\text { protein UreD }\end{array}$ & 308 & [39] \\
\hline Glyma20g17990 & Not described & 2786 & $\begin{array}{c}\text { Accessory } \\
\text { protein UreD }\end{array}$ & 256 & - \\
\hline Glyma02g44440 & EU2 & 717 & $\begin{array}{c}\text { Accessory } \\
\text { protein UreF }\end{array}$ & 238 & {$[40]$} \\
\hline Glyma14g04380 & Not described & 2032 & $\begin{array}{c}\text { Accessory } \\
\text { protein UreF }\end{array}$ & 238 & {$[40]$} \\
\hline Glyma08g08970 & Eu3 & 4000 & $\begin{array}{c}\text { Accessory } \\
\text { protein UreG }\end{array}$ & 285 & {$[41]$} \\
\hline
\end{tabular}

Table 1. Urease-related genes in soybean

\section{The Intricate Process of Urease Activation - Much More Than Structural Genes}

The biosynthesis of metalloenzymes usually depends on the participation of several dedicated proteins that are essential for the correct assembly of their active sites, and ureases are no exception. The role of these accessory proteins consist on the stabilization of the apoenzyme in a certain conformation that allows the correct insertion of the metal ion in the active site, dissociating afterwards and releasing the mature enzyme [42]. This process has been fairly studied for bacterial ureases, but the activation of plant ureases still demands more attention. Thus it is described here based mostly on what is known for bacterial ureases.

The activation of ureases require two essential steps: the carbamylation of a lysine residue, that will be responsible for bridging and, consequently, holding the two $\mathrm{Ni}^{2+}$ ions into place within the active site; and the actual incorporation of the two $\mathrm{Ni}^{2+}$ ions in the active site. The best characterized system so far is that of Klebsiella aerogenes urease, for which four accessory proteins, namely UreD, UreE, UreF and UreG, are required for complete activation [2]. Although many efforts have been put on characterizing these proteins, the precise role of each one in the complex process of urease activation is still not clearly understood. These proteins appear to be well conserved among urease producing bacterial organisms and even for higher organisms as plants. In K. aerogenes, the accessory proteins bind consecutively to the apourease (apU) forming the following complexes: apU-UreD, apU-UreDF, apU-UreDFG $[2,43]$. UreE, a Ni ${ }^{2+}$ binding protein, is the last accessory protein proposed to bind to the complex apU-UreDFG and deliver the metal to the enzyme active site [44]. The process of urease activation requires the 
hydrolysis of GTP by UreG, after which the accessory proteins dissociate from the active enzyme. A preformed UreDFG complex could be isolated from bacteria lacking UreE [45]. If the accessory proteins act on apU as a preformed complex or in a sequential binding fashion, is a matter that demands further investigation. However, the sequential binding model is to date the most accepted and the one supported by most evidence.

Although the exact role of each accessory protein has not been clearly assigned, some general lines can be traced for their individual actions. The current sequential model assumes that UreD is the first accessory protein to interact with urease. UreD is yet the least characterized protein and it seems to serve as an adapter for the other accessory proteins since neither UreF or UreG are able to bind urease directly in the absence of UreD [2]. UreF interacts directly with UreD and it has been proposed that UreF would be responsible for promoting a conformational change in apU, providing better access to the active site of the protein and allowing the next steps of the process to take place [46]. Recently, a structural model of UreF has indicated that this protein shares structural similarities to some GTP activating proteins (GAP) [47]. UreG is an intrinsically disordered GTPase, as reported for organisms such as Helicobacter pylori, Bacillus pasteurii, Micobacterium tuberculosis and also Glycine max [48-53]. UreG binds to UreF and, through the cleavage of GTP, provides the necessary energy for the activation process. It is also postulated that GTP cleavage in the presence of $\mathrm{CO}_{2}$ could form carboxyphosphate, an excellent carbamylation agent [46, 54]. UreG GTPase activity, when detectable, seems to be very low in comparison to other GTPases. It has been proposed [46] that the intrinsically disordered structure of this enzyme serves as a regulatory mechanism of its activity, which would be only maximized when, inserted in the activating complex, it acquires its fully folded state. It is also hypothesized that UreF would act on UreG as a GAP, enhancing its enzymatic activity, although, this hypothesis still waits to be tested.

Available sequences of bacterial urease accessory proteins led to the search of potential orthologs in plants, and the identification of UreG (Eu3) in soybean. This was the first evidence of accessory proteins in plants [41]. Soybean cDNAs for UreD and UreF proteins were also identified later [39], but none of them were assigned as the Eu2 gene. To date, no UreE equivalent in plants has been identified and sequence analyses supports the hypothesis that its functionality is incorporated into UreG which, in plants but not in bacteria, presents an extended N-terminal rich in aspartic acid and histidine residues. The property of soybean UreG to bind metal ions has been demonstrated [41, 53]. A study in A. thaliana [55] has shown that UreD, UreF and UreG are necessary and sufficient to activate urease, since knockout plants for any of the accessory proteins genes lack urease activity. They also showed that simultaneous co-expression of all accessory proteins together with $A$. thaliana urease structural gene was able to generate urease activity on Escherichia coli cells. Also the Oriza sativa urease could only be activated when all of its three accessory proteins were cotransformed in tobacco [56].

With the exception of dimeric ureases described for some plants, such as canatoxin from $C$. ensiformis [5], and the ureases from Morus alba [57] and Momordica charantia [58], all reported ureases share a basic trimeric state that may aggregate to form larger oligomers, as hexamers in the case of most plant ureases, in which each monomer carries one active site. For bac- 
teria, each unit of this trimer is usually itself a heterotrimer composed by the subunits UreA, UreB and UreC which co-align with plant ureases with over $50 \%$ identity. Thus the single type polypeptide chain of plant ureases corresponds to the collinear fusion of the bacterial subunits (UreA-UreB-UreC). It is curious to notice that despite the high similarity between plant and bacterial ureases, some of the accessory proteins do not share the same degree of sequence identity. Plant and bacterial UreG are very similar, with about $40 \%$ of sequence identity, but plant UreD and UreF share only about $20 \%$ of sequence identity with their bacterial counterparts [56]. Considering this discrepancy, a recent work using in silico structure prediction tools, has shown that despite the sequence disparities, UreF proteins are very conserved at the structural level [56]. Plant UreD, although sharing some structural similarities, possess some marked differences when compared to their bacterial counterparts. This different overall structure of plant and bacterial UreD is hypothesized to reflect distinct requirements for interaction with the bacterial heterotrimeric or the plant single polypeptide urease unit [56].

Despite the fact that the presence of the set of accessory proteins is enough to get ureases activated, there seems to be more to it concerning regulation. In bacteria, UreF and UreD are expressed in very low levels, and it has been shown that over expression of these proteins can hamper urease activation $[59,60]$. It has been proposed that differential splicing generating aberrant mRNA could reduce UreD production in plants [55]. Cao and co-workers [56] reported for ureF an intron in the 5'leader conserved among 16 plant genomes and they noticed that in almost every case the spliced transcript would be free of AUG codons upstream of the start codon. Special attention was given to the two ureF genes from soybean which, although both are spliced at the 5' leader, only the paralog in chromosome 2 (Glyma02g44440) has all the nonstart AUG codons removed. The transcript of the paralog from chromosome 14 (Glyma14g04380) has an out of frame AUG codon upstream of the start codon and therefore was postulated to be ineffectively translated and consequently non functional. In the same work, a low splicing efficiency of AtureF was observed, which led to the conclusion that for some plants the $5^{\prime}$ leader sequence may have a regulatory role in reducing the amount of ureF mRNA either by differential splicing (Arabidopsis) or translational inhibition (soybean). Limited expression may be required to ensure that UreF and UreD dissociate from urease after activation to release the active enzyme and that the putative GTPase activating protein UreF does not trigger UreG activity in the absence of urease [56]. Both UreD and UreF have been observed to be very unstable proteins either in plants [56] or bacteria [59], and this intrinsic instability possibly contributes to the regulation of their activities in vivo [56].

As mentioned above, soybean genome contains two UreF genes. The one in chromosome 14 UreF (Ch14UreF) has previously been characterized and demonstrated to activate the urease from S. pombe [39], but the UreF encoded by chromosome 2 (Ch02UreF) remains to be characterized. Until recently, the product of Eu2 gene was not identified, and it had been proposed that Eu2 could represent the functional paralog of UreD or UreF. Analysis of soybean Eu2 mutants revealed that missense mutations resulted in the expression of an altered form of Ch02UreF protein [40]. Interestingly, these mutants presented no urease activity, even 
though the Ch14UreF is present and is supposed to activate urease. Another mutant, in which the expression of Ch02UreF was impaired, presented 5-10\% of the wild type urease activity. The authors presented two possible explanations for the results. The first one considered that Ch02UreF could spoil activation by Ch14UreF because of a higher affinity for the activation complex. The second explanation, favoured in their work, proposed that Ch02UreF is more abundant than Ch14UreF, which would be less efficiently translated. Therefore, in Eu2 mutants, the missense mutants of Ch02UreF block the access of Ch14UreF to the urease activation complex, preventing activation [40].

As pointed out here, although accessory proteins differ widely according to their source, the process of urease activation seems to be very well conserved. Among plants, the urease activation complex seems to be structurally very similar, since accessory proteins from different plants are able to functionally complement each other. Rice urease, for instance, can be activated by Arabidopsis bulk of accessory proteins, and UreD and UreG from rice can replace the native accessory protein in mutants of Arabidopsis [56]. The similarities of the activation process seem also to break the kingdom barrier. Soybean UreF has been shown to complement the Saccharomyces pombe accessory set [39], and UreG from potato (Solanum tuberosum) complements the K. aerogenes operon [61].

\section{The Physiological Role of Soybean Ureases}

After carbon, nitrogen is the main limiting element for plant performance [62], and there is a constant pressure on plants for efficient use of $\mathrm{N}$ leading to the development of efficient mechanisms for $\mathrm{N}$ uptake and metabolic pathways for $\mathrm{N}$ remobilization $[37,56]$. Such a pressure even led to a reduction of $\mathrm{N}$ content of plant proteins [63]. Urea is an important primary source of $\mathrm{N}$ for plants. The action of arginase is the only confirmed pathway for urea generation in vivo; urea could also be generated by the degradation of purines and ureides [64], although this later pathway is very controversial. Urea can only be assimilated after its hydrolysis into ammonia and carbon dioxide by urease [65], and that is the main physiological role attributed to ureases in plants [37]. Ammonia will then be re-assimilated by glutamine synthetase using glutamate as substrate [66]. Urease activity is present virtually in all plant species and is ubiquitously distributed in all plant tissues [18, 31, 67], which is indicative of the great importance of its physiological role for the whole plant. For a long time, the relevance of plant urease-mediated metabolism of urea was considered not significant, since it was assumed that urea was hardly taken up by the plants, but instead degraded by microorganisms in the soil and then the ammonia and nitrate were absorbed. Today, it is well known that plants can actively import urea from the soil, through the activity of dedicated urea transporters [68] and can also efficiently process soil-imported urea, even at high concentrations. These findings point at urease as a target for studies on improving plant $\mathrm{N}$ metabolism based on urea, the most used $\mathrm{N}$ fertilizer in the world [69].

Soybean makes a very interesting model for studies on the physiological role of urease in plants, since it is so far the only genome-sequenced plant that presents more than one isoform 
of the enzyme. ub-SBU has long been known to be the isoform responsible for recycling all metabolically derived urea [19, 70, 71]. This has been demonstrated since mutants lacking esSBU do not accumulate urea in any tissue and do not have any impairment on the use of urea as sole nitrogen source, even though ub-SBU is present at levels only 0.1 to $0.3 \%$ that of es-SBU $[19,72]$. Soybean mutants lacking ub-SBU activity present a characteristic phenotype consisting of necrosis of leaf tips, due to urea "burn", and accumulation of urea in many tissues [32, 36]. Urease is the only $\mathrm{Ni}^{2+}$ dependent enzyme yet identified in plants and the same phenotype, early mentioned, is observed for plants grown under $\mathrm{Ni}^{2+}$ deprivation [27].

Interestingly, no physiological role, being it assimilatory or of any other nature, could be demonstrated for the very abundant es-SBU. In fact, wild-type cultured cotyledons could not grow in the presence of urea, due to a sudden $\mathrm{pH}$ increase resultant of an uncontrolled ammonia release. The same effect was not observed for mutants that have only ub-SBU [36]. It was inferred that es-SBU could be involved in plant defense against predators. A chemical protection was postulated for the case of microbial or insect attack. By this model, wounding or infection of the immature embryo would lead to arginase release from ruptured mitochondria which would generate urea from the large pool of arginine and cytoplasmic urease would rapidly convert urea to ammonia [32]. This hypothesis still waits demonstration, but it has been reported that mutants lacking urease activity were more susceptible to microbial infections [73]. As it will be discussed in the next section, es-SBU can be involved in plant defense not only by conferring chemical protection, but also ureolysis-independent mechanisms, including the generation of toxic peptides. On the other hand, it is tempting to propose that the third urease found in the soybean genome (Glyma08g10850), that apparently has no enzymatic activity, can also be involved in other physiological roles in the plant, such as plant defense, and some indications of that have already been reported (see the next section).

\section{New features of an old protein - activities unrelated to the enzymatic one}

As stated above, no definite answer to the question of the physiological relevance of es-SBU has been given, since the demonstration that this enzyme plays no role in nitrogen assimilation from urea $[32,65,73]$. During the course of the last decade, a number of biological properties unrelated to the enzymatic activity were described for plant ureases, launching a new look over these proteins and their physiological roles. Table 2 summarizes some of these overlooked biological activities of plant ureases. The main discoveries were made for the jackbean ureases (CNTX and JBU), revealing several interesting properties, such as entomotoxicity [74-77], fungitoxicity [78, 79] and secretory activity $[5,80]$.

Some of the biological properties described for jackbean's ureases, such as the entomotoxic and fungitoxic activities, are shared by soybean urease. es-SBU displays toxicity toward insects, as demonstrated by [75]. es-SBU is toxic to Dysdercus peruvianus, a cotton culture pest, at doses as low as $0.05 \%(\mathrm{w} / \mathrm{w})$, causing a decrease on insect body weight, delayed develop- 
ment and death. This toxicity was maintained after treating es-SBU with $p$-hydroxymercuribenzoate (an irreversible urease inhibitor), confirming that the entomotoxic property was independent of the enzymatic activity. For the jackbean ureases, it has been demonstrated that this entomotoxic effect is a highly complex event, involving the intact protein as well as the release of a toxic peptide $[82,89,90]$. Jackbean ureases and their derived peptides affect several physiological processes in the insects, including the fluid transport across membranes $[83,91,92]$. So far, no studies regarding es-SBU mechanism of action in insects were performed, but it reasonable to assume that, due to their very similar sequences $(92 \%$ of similarity), es-SBU and JBU would have the same targets in these organisms. The sequence of the entomotoxic peptide identified in CNTX and JBU, is present in es-SBU and ub-SBU [90]. These findings also support the hypothesis of a similar mode of action in insects.

\begin{tabular}{|c|c|c|c|c|}
\hline Activity & CNTX & JBU & es-SBU & GHU \\
\hline Entomotoxic & $\begin{array}{l}\text { Rhodnius prolixus, } \\
\text { Callosobruchus } \\
\text { maculatus [74], Nezara } \\
\text { viridula [81], Dysdercus } \\
\text { peruvianus }[75,76]\end{array}$ & $\begin{array}{c}\text { Dysdercus peruvianus [75, 76, } \\
\text { 82], Rhodnius prolixus [83] } \\
\text { Oncopeltus fasciatus [77] }\end{array}$ & $\begin{array}{c}\text { Dysdercus } \\
\text { peruvianus [75] }\end{array}$ & N.D. \\
\hline Fungitoxic & $\begin{array}{c}\text { Macrophomina } \\
\text { phaseolina, } \\
\text { Colletotrichum } \\
\text { gloesporioides, } \\
\text { Sclerotium rolfsii [78] }\end{array}$ & $\begin{array}{c}\text { Fusarium solani, } \\
\text { Colletotrichum musae, } \\
\text { Curvularia lunata, Penicillium } \\
\text { herguei, Fusarium oxysporum } \\
\text { [79]. }\end{array}$ & $\begin{array}{l}\text { Colletotrichum } \\
\text { musae, Penicillium } \\
\text { herguei, Curvularia } \\
\text { lunata, Fusarium } \\
\text { oxysporum [79]. }\end{array}$ & $\begin{array}{c}\text { Colletotrichum } \\
\text { musae, Penicillium } \\
\text { herguei, Curvularia } \\
\text { lunata [84]. }\end{array}$ \\
\hline Secretory & $\begin{array}{l}\text { Rabbit platelets [85, } \\
\text { 86], rat brain } \\
\text { synaptosomes [86], rat } \\
\text { pancreatic cells [87], rat } \\
\text { mast cells [88] }\end{array}$ & Rabbit platelets $[5,75]$ & $\begin{array}{c}\text { Rabbit platelets } \\
\text { [75] }\end{array}$ & N.D. \\
\hline $\begin{array}{l}\text { Toxicity to } \\
\text { mammals }\end{array}$ & $2 \mathrm{mg} / \mathrm{kg}\left(\mathrm{LD}_{50}\right)[5]$ & Not toxic [75] & Not toxic [75] & N.D. \\
\hline
\end{tabular}

Table 2. Properties of plant ureases unrelated to the enzymatic activity; N.D. = not determined; GHU = Gossypium hirsutum urease

Another very interesting property presented by es-SBU is its fungitoxic activity. es-SBU suppressed mycelial growth and/or inhibited spore germination of a series of fungi species and, as demonstrated for the entomotoxic property, this effect also does not require the protein's ureolytic activity [79]. The precise mechanism of action of ureases on fungi has not been elucidated so far, being proposed that ureases may interfere with the cellular osmotic balance. Recently, evidences of the participation of ub-SBU in soybean resistance to fungi were reported [93]. Soybeans mutants, lacking ub-SBU, were more susceptible to necrotrophic fungi, such as Penicillium herguei, Phomopsis sp and Rhizoctonia solani, and to the biotrophic 
pathogen Phakopsora pachyrhizi, responsible for the Asian soybean rust disease. In accordance to a defense role of ub-SBU against fungi infection, a rust-resistant soybean cultivar (PI561356) had a higher level of expression of ub-SBU after infection with P. pachyrhizi, in comparison with a susceptible cultivar (Embrapa-48) [93].

These toxic activities, unrelated to the ureolytic one, are interesting findings that point to a possible role of ureases in plant defense against insects and fungi. However, plant ureases also have others bioactivities, that seem not related to plant physiology. JBU and es-SBU were shown to activate exocytosis in blood platelets causing them to aggregate, an effect shown to be independent of their enzymatic activity [75]. This exocytosis-inducing property may be relevant to some urease-producing microorganisms such as Bacillus pasteurii and Helicobacter pylori $[94,95]$ but it is unlikely to have a more specific significance for plants. Nevertheless, Carlini and Polacco [73] hypothesized that the secretion-properties of bacterial and plants ureases may play a role in rhizosphere relationships.

\section{Soybean as animal feed - what urease has got to do with it?}

It is estimated that soybean meal accounts for around $67 \%$ of all protein sources used in animal feeds around the world [96], due mainly to its high protein concentration (44 to 48\%) [97]. Nevertheless, soybean contains an unusually large number of bioactive compounds with antinutritional and/or toxic properties, which have a negative effect on body metabolism of animals [98]. Urease is one of these factors. Urease content was not evidently different among 11 soybean cultivars tested [99]. In contrast, urease content was found very variable among several other soybean cultivars [100-102], and the levels of urease correlated positively with antinutritional effects in rats [101].

The negative effects of using urease-containing meals as animal feed are reported in the literature. Urea is frequently added to animal feed and, when unprocessed soybeans are mixed with urea, ammonia will be released by the action of urease, which is an undesired effect in a mixed feed [103]. In ruminants, ammonia rapidly enters the blood and can cause adverse affects ranging from depressed feed intake and animal performance, to death from ammonia toxicity [104]. In dairy cows, the liver, responsible for removing potentially toxic ammonia from circulation, was able to remove ammonia added to portal blood until the supply reached $182 \mathrm{mg} / \mathrm{min}$ but, at higher infusion rates, peripheral blood ammonia concentrations increased, supporting the assessment that a rapid hydrolysis of dietary urea can exceed the liver's capacity to remove it [105]. In chickens, it was demonstrated that soybean meals from one particular source consistently produced a high incidence of tibial dyschondroplasia (TD) and the most striking difference between the meals was the high antitrypsin and urease values in those that induced the disease [106]. The incidence of TD was demonstrated previously to be increased in broilers when ammonium chloride (1.5 or $30 \%)$ was added to the diet [107], but not when calcium chloride was used [108]. These may be indications that the release of ammonia by urease could play a role in the incidence of TD in soybean meal fed chickens. 
In order to allow the addition of supplemental nitrogen to the animal feed, while protecting the animals against the production of toxic levels of ammonia, pre-treatment of the soybean meal is necessary. Heat treatment is the main method used to abolish or decrease the effects of the antinutritional and/or toxic factors in soybean, including urease [109, 110], but these treatments should be kept to a minimum, due to the possibility of destroying important seed constituents [98]. To abolish urease activity, several treatments are effective, including steam-heating at $102{ }^{\circ} \mathrm{C}$ for $40 \mathrm{~min}$ or at $120^{\circ} \mathrm{C}$ for $7.5 \mathrm{~min}$ [109], boiling at $92{ }^{\circ} \mathrm{C}$ for $60 \mathrm{~min}$ [101], and dry-heating at $100{ }^{\circ} \mathrm{C}$ and $2 \mathrm{kgf} / \mathrm{cm}^{2}$ for $60 \mathrm{~min}$ [111]. All those treatments abolished urease activity, along with a decrease of several antinutritional factors.

The best way to evaluate the adequacy of the processing and final quality of soybean meals is conducting biological tests. However, the cost, time requirement and complexity of these tests impair their use. Since the 1940's, the urease test is used as an indirect way to evaluate the adequacy of heat processing of soybeans due to its rapidity, low skill and minimum amount of laboratory equipment requirements. One research study [109] showed a high correlation among the activities of trypsin inhibitors, urease and lectins, indicating that the adequacy of soybean processing can be estimated to a considerable extent by these analytical criteria. Over the years, many protocols were developed to facilitate the measurement of urease activity. These protocols quantify the released ammonia directly or indirectly. One of the first to be developed, in the Caskey-Knapp method [112] the meal is incubated with urea in a buffered solution and then phenol red is added. After incubation, insufficiently processed meals will cause an increase in the $\mathrm{pH}$ of the solution, indicated by a change in color (from red-orange to pink), while adequately processed meals produce little or no color change. One study [113] proposed an alternative method, with the potential to differentiate between meals with low levels of urease activity, based on the incubation of the meal with urea in a buffered solution and the colorimetric determination of the residual urea with $p$ dimethylaminobenzaldehyde. A method for direct titration of ammonia as a measure of urease activity was proposed [114] and adapted [115], in which the incubation of urea and the meal is performed, maintaining the $\mathrm{pH}$ of the solution by slowly adding $\mathrm{HCl}$. The system is then titrated with $\mathrm{NaOH}$. The difference in titration between a control (urease inactivated) and the sample is taken as the urease activity of the meal. Two other methods were developed to determine ammonia directly, based on the phenol-hypochlorite reaction [116, 117].

Several modifications and adaptations of these methods were developed during time. But, regardless of the method chosen, urease activity is a very good indicator of under processing of soybean meals. It is worth noting, however, that this activity is not a good indicator of over processing of soybean meals.

\section{The biotechnological potential of soybean ureases}

The questions of why are ureases so large, and why are they multimeric have been raised, and a possible explanation is that a "primordial" enzyme could have acquired other "traits" under the evolutionary pressure of competition in an increasingly complex biosphere [73]. 
In the view of these "extra traits" discovered for ureases, some biotechnological applications can now be proposed.

Soybean can be attacked by many different organisms, including fungi, insects, virus and nematodes. These pathogens and pests can cause damage in seeds, roots, leaves, stems and pods, and usually are tissue-specific [118]. And, despite control measures, pests reduce worldwide soybean production by almost $28 \%$ [119]. The development of new technologies to control these pests is urgent, and exploring natural plant compounds is a major strategy.

Plant ureases and their derived peptides have a great biotechnological potential. Ureases are abundant in many edible sources, including legumes and potatoes, and even eaten raw in cucumbers, or fruits such as melon and watermelon [73]. Thus, possible biosafety issues could be more manageable. Since JBU, es-SBU and the derived peptide Jaburetox seem non toxic to mammals $[75,90]$, the entomotoxic and fungitoxic properties of these molecules are relevant when considering biotechnological strategies aiming to protect commercially-relevant crops against natural enemies. The evidences of an in vivo effect of soybean urease in protecting the plant from fungi [93] are exciting. The possibility of selecting soybean cultivars with higher urease content or increasing the production of these proteins in the plant through genetic manipulation, in order to increase the resistance against insects and fungi, is very promising. Also, the premise of using plant naturally occurring proteins to improve resistance seems much more appealing to the general public than the alternative of inserting foreign genes (from microorganisms or animals) into crops.

As pointed out a long time ago [15, 120], soybeans with a high content of ureases could also be agronomically valuable, regardless of the defense role, for permitting more efficient assimilation of urea fertilizer by the plant. Also, considering the wide use of soybean meal as animal feed (as discussed above) and the potential of being a protein source for humans, a higher urease content in soybean could be interesting for improving soybean nutritional quality, after the appropriated processing, since urease is richer in methionine than many others soybean seed proteins. Soybean has a limited amount of sulfur aminoacids, almost half of which are considered ideal for animal feed. Although this problem can be overcome by feed supplementation with free methionine, there are problems associated with the supplementation, such as leaching of methionine during processing and bacterial degradation leading to formation of undesirable volatile sulfides [121]. Improving the content of methionine in soybean through the increase of the biosynthesis of endogenous proteins, such as ureases, is a very interesting approach.

\section{Conclusion}

Soybean ureases were undoubtedly landmarks in science, being the subject of investigations since the beginning of the 1900's. But, despite the more than one century of studies, we still have a long way until fully understanding the complexity of such a striking molecule. The many properties of these proteins revealed that ureases are much more than urea hydrolyzing enzymes, and present a vast array of interesting biotechnological applications. Exploring 
the toxic properties of plant ureases can be of great interest for the development of alternative strategies to protect agricultural relevant crops against several natural enemies.

\section{Acknowledgements}

The authors are thankful for the Brazilian funding agencies Conselho Nacional de Desenvolvimento Científico e Tecnológico (CNPq), Coordenação de Aperfeiçoamento de Pessoal de Nível Superior (CAPES) and Fundação de Amparo à Pesquisa do Estado do Rio Grande do Sul (FAPERGS).

\section{Author details}

Rafael Real-Guerra ${ }^{1 *}$, Fernanda Stanisçuaski ${ }^{2}$ and Célia Regina Carlini ${ }^{1,3}$

*Address all correspondence to: rafael.guerra@ufrgs.br

1 Center of Biotechnology, Federal University of Rio Grande do Sul, Porto Alegre, Brazil

2 Department of Molecular Biology and Biotechnology, Biosciences Institute, Federal University of Rio Grande do Sul, Porto Alegre, Brazil

3 Department of Biophysis, Biosciences Institute, Federal University of Rio Grande do Sul, Porto Alegre, Brazil

\section{References}

[1] Blakeley, R. L., Hinds, J. A., Kunze, H. E., Webb, E. C., \& Zerner, B. (1969). Jack Bean Urease (Ec 3.5.1.5). Demonstration of a Carbamoyl-Transfer Reaction and Inhibition by Hydroxamic Acids. Biochemistry, 8(5), 1991-2000.

[2] Carter, E. L., Flugga, N., Boer, J. L., Mulrooney, S. B., \& Hausinger, R. P. (2009). Interplay of Metal Ions and Urease. Metallomics, 1(3), 207-221.

[3] Sumner, J. B. (1926). The Isolation and Crystallization of the Enzyme Urease. Journal of Biological Chemistry, 69-435.

[4] Dixon, N. E., Gazzola, T. C., blakeley, R. L., \& Zermer, B. (1975). Jack Bean Urease (Ec 3.5.1.5). A Metalloenzyme. A Simple Biological Role for Nickel? Journal of the American Chemical Society, 97(14), 4131-4133.

[5] Follmer, C., Barcellos, G. B., Zingali, R. B., Machado, O. L., Alves, E. W., Barja-Fidalgo, C., Guimaraes, J. A., \& Carlini, C. R. (2001). Canatoxin, a Toxic Protein from Jack 
Beans (Canavalia Ensiformis), Is a Variant Form of Urease (Ec 3.5.1.5): Biological Effects of Urease Independent of Its Ureolytic Activity. Biochemical Journal [Pt 1], 217 .

[6] Carter, E. L., Tronrud, D. E., Taber, S. R., Karplus, P. A., \& Hausinger, R. P. (2011). Iron-Containing Urease in a Pathogenic Bacterium. Proceedings of the National Academy of Sciences of the United States of America, 108(32), 13095-13099.

[7] Takeuchi, T. (1909). On the Occurence of Urease in Higher Plants. Journal of the College of Agriculture, Imperial University of Tokyo, 1.

[8] Van Slyke, D. D., \& Cullen, G. E. (1914). The Mode of Action of Urease and Enzymes in General. Journal of Biological Chemistry, 19-141.

[9] Fishbein, W. N., Spears, C. L., \& Scurzi, W. (1969). Spectrum of Urease Isozymes: Genetic, Polymeric and Conformeric. Nature, 223(5202), 191-193.

[10] Fishbein, W. N., \& Nagarajan, K. (1971). Urease Catalysis and StructureVii. Factors Involved in Urease Polymerization and Its Kinetic Pattern. Archives of Biochemistry and Biophysics, 144(2), 700-714.

[11] Fishbein, W. N., Nagarajan, K., \& Scurzi, W. (1976). Urease Catalysis and StructureX. Alternate Bonding-Site Isozymes of Jackbean Urease. Archives of Biochemistry and Biophysics, 172(2), 726-733.

[12] Creeth, J. M., \& Nichol, L. W. (1960). Evidence for the Chemical Interaction of Urease in Solution. Biochemical Journal, 77-230.

[13] Lynn, K. R. (1971). Urease: Two Active Forms. Enzymologia, 40(2), 145-150.

[14] Buttery, B. R., \& Buzzell, R. I. (1971). Properties and Inheritance of Urease Isozymes in Soybean Seeds. Canadian Journal Of Botany, 49, 1101-1105.

[15] Polacco, J. C., \& Havir, E. A. (1979). Comparisons of Soybean Urease Isolated from Seed and Tissue Culture. Journal of Biological Chemistry, 254(5), 1707-1715.

[16] Polacco, J. C., Thomas, A. L., \& Bledsoe, P. J. (1982). A Soybean Seed Urease-Null Produces Urease in Cell Culture. Plant Physiology, 69(5), 1233-1240.

[17] Kerr, P. S., Blevins, D. G., Rapp, B. J., \& Randall, D. D. (1983). Soybean Leaf Urease: A Comparison with Seed Urease. Physiologia Plantarum, 57, 339-345.

[18] Polacco, J. C., \& Winkler, R. G. (1984). Soybean Leaf Urease: A Seed Enzyme? Plant Physiology, 74(4), 800-803.

[19] Polacco, J. C., Krueger, R. W., \& Winkler, R. G. (1985). Structure and Possible Ureide Degrading Function of the Ubiquitous Urease of Soybean. Plant Physiology, 79(3), 794-800.

[20] Kloth, R. H., \& Hymowitz, T. (1985). Re-Evaluation of the Inheritance of Urease in Soybean Seed. Crop Science, 25(2), 352-354. 
[21] Winkler, R. G., Polacco, J. C., Eskew, D. L., \& Welch, R. M. (1983). Nickel Is Not Required for Apourease Synthesis in Soybean Seeds. Plant Physiology, 72(1), 262-263.

[22] Krueger, R. W., Holland, MA, Chisholm, D., \& Polacco, J. C. (1987). Recovery of a Soybean Urease Genomic Clone by Sequential Library Screening with Two Synthetic Oligodeoxynucleotides. Gene, 54(1), 41-50.

[23] Meyer-Bothling, L. E., Polacco, J. C., \& Cianzio, S. R. (1987). Pleiotropic Soybean Mutants Defective in Both Urease Isozymes. Molecular and general genetics, 209(3), 432-438.

[24] Kloth, R. H., Polacco, J. C., \& Hymowitz, T. (1987). The Inheritance of a Urease-Null Trait in Soybeans. Theoretical and Applied Genetics, 73(3), 410-418.

[25] Holland, M. A., Griffin, J. D., Meyerbothling, L. E., \& Polacco, J. C. (1987). Developmental Genetics of the Soybean Urease Isozymes. Developmental Genetics, 8(5-6), 375-387.

[26] Polacco, J. C., Judd, A. K., Dybing, J. K., \& Cianzio, S. R. (1989). A New Mutant Class of Soybean Lacks Urease in Leaves but Not in Leaf-Derived Callus or in Roots. Molecular and General Genetics, 217(2-3), 257-262.

[27] Eskew, D. L., Welch, R. M., \& Cary, E. E. (1983). Nickel: An Essential Micronutrient for Legumes and Possibly All Higher Plants. Science, 222(4624), 621-623.

[28] Eskew, D. L., Welch, R. M., \& Norvell, W. A. (1984). Nickel in Higher Plants: Further Evidence for an Essential Role. Plant Physiology, 76(3), 691-693.

[29] Holland, M. A., \& Polacco, J. C. (1992). Urease-Null and Hydrogenase-Null Phenotypes of a Phylloplane Bacterium Reveal Altered Nickel Metabolism in Two Soybean Mutants. Plant Physiology, 98(3), 942-948.

[30] Polacco, J. C., Freyermuth, S. K., Gerendas, J., \& Cianzio, S. R. (1999). Soybean Genes Involved in Nickel Insertion into Urease. Journal of Experimental Botany, 50(336), 1149-1156.

[31] Torisky, R. S., \& Polacco, J. C. (1990). Soybean Roots Retain the Seed Urease Isozyme Synthesized During Embryo Development. Plant Physiology, 94(2), 681-689.

[32] Polacco, J. C., \& Holland, M. A. (1993). Roles of Urease in Plant-Cells. International Review of Cytology-a Survey of Cell Biology, 145, 65-103.

[33] Torisky, R. S., Griffin, J. D., Yenofsky, R. L., \& Polacco, J. C. (1994). A Single Gene (Eu4) Encodes the Tissue-Ubiquitous Urease of Soybean. Molecular \& General Genetics, 242(4), 404-414.

[34] Goldraij, A., Beamer, L. J., \& Polacco, J. C. (2003). Interallelic Complementation at the Ubiquitous Urease Coding Locus of Soybean. Plant Physiology, 132(4), 1801-1810.

[35] Schmutz, J., Cannon, S. B., Schlueter, J., Mitros, J., Nelson, T., Hyten, W., Song, D. L., Thelen, Q., Cheng, J. J., Xu, J., Hellsten, D., May, U., Yu, G. D., Sakurai, Y., Umezawa, 
T., Bhattacharyya, T., Sandhu, M. K., Valliyodan, D., Lindquist, B., Peto, E., Grant, M., Shu, D., Goodstein, S., Barry, D., Futrell-Griggs, K., Abernathy, M., Du, B., Tian, J., Zhu, Z., Gill, L., Joshi, N., Libault, T., Sethuraman, M., Zhang, A., -C, X., Shinozaki, K., Nguyen, H. T., Wing, R. A., Cregan, P., Specht, J., Grimwood, J., Rokhsar, D., Stacey, G., Shoemaker, R. C., \& Jackson, S. A. (2010). Genome Sequence of the Palaeopolyploid Soybean. Nature, 463(7278), 178-183.

[36] Stebbins, N., Holland, MA, Cianzio, S. R., \& Polacco, J. C. (1991). Genetic Tests of the Roles of the Embryonic Ureases of Soybean. Plant Physiology, 97(3), 1004-1010.

[37] Witte, C. P. (2011). Urea Metabolism in Plants. Plant Science, 180(3), 431-438.

[38] Joint Genome Institute- University of California Regents. (2011). Phytozome. http:// www.phytozome.net/.

[39] Bacanamwo, M., Witte, CP, Lubbers, M. W., \& Polacco, J. C. (2002). Activation of the Urease of Schizosaccharomyces Pombe by the Uref Accessory Protein from Soybean. Molecular Genetics and Genomics, 268(4), 525-534.

[40] Polacco, J. C., Hyten, D. L., Medeiros-Silva, M., Sleper, D. A., \& Bilyeu, K. D. (2011). Mutational Analysis of the Major Soybean Uref Paralogue Involved in Urease Activation. Journal of Experimental Botany, 62(10), 3599-3608.

[41] Freyermuth, S. K., Bacanamwo, M., \& Polacco, J. C. (2000). The Soybean Eu3 Gene Encodes an Ni-Binding Protein Necessary for Urease Activity. Plant Journal, 21(1), 53-60.

[42] Kuchar, J., \& Hausinger, R. P. (2004). Biosynthesis of Metal Sites. Chemical Reviews, 104(2), 509-525.

[43] Park, I. S., \& Hausinger, R. P. (1995). Evidence for the Presence of Urease Apoprotein Complexes Containing Ured, Uref, and Ureg in Cells That Are Competent for in Vivo Enzyme Activation. Journal of Bacteriology, 177(8), 1947-1951.

[44] Soriano, A., Colpas, G. J., \& Hausinger, R. P. (2000). Uree Stimulation of Gtp-Dependent Urease Activation in the Ured-Uref-Ureg-Urease Apoprotein Complex. Biochemistry, 39(40), 12435-12440.

[45] Moncrief, M. B., \& Hausinger, R. P. (1997). Characterization of Ureg, Identification of a Ured-Uref-Ureg Complex, and Evidence Suggesting That a Nucleotide-Binding Site in Ureg Is Required for in Vivo Metallocenter Assembly of Klebsiella Aerogenes Urease. Journal of Bacteriology, 179(13), 4081-4086.

[46] Zambelli, B., Musiani, F., Benini, S., \& Ciurli, S. (2011). Chemistry of Ni2+ in Urease: Sensing, Trafficking, and Catalysis. Accounts of Chemical Research, 44(7), 520-530.

[47] Salomone-Stagni, M., Zambelli, B., Musiani, F., \& Ciurli, S. (2007). A Model-Based Proposal for the Role of Uref as a Gtpase-Activating Protein in the Urease Active Site Biosynthesis. Proteins, 68(3), 749-761. 
[48] Zambelli, B., Stola, M., Musiani, F., De Vriendt, K., Samyn, B., Devreese, B., Van Beeumen, J., Turano, P., Dikiy, A., Bryant, D. A., \& Ciurli, S. (2005). Ureg, a Chaperone in the Urease Assembly Process, Is an Intrinsically Unstructured Gtpase That Specifically Binds Zn2+. Journal of Biological Chemistry, 280(6), 4684-4695.

[49] Neyroz, P., Zambelli, B., \& Ciurli, S. (2006). Intrinsically Disordered Structure of Bacillus Pasteurii Ureg as Revealed by Steady-State and Time-Resolved Fluorescence Spectroscopy. Biochemistry, 45(29), 8918-8930.

[50] Zambelli, B., Musiani, F., Savini, M., Tucker, P., \& Ciurli, S. (2007). Biochemical Studies on Mycobacterium Tuberculosis Ureg and Comparative Modeling Reveal Structural and Functional Conservation among the Bacterial Ureg Family. Biochemistry, 46(11), 3171-3182.

[51] Zambelli, B., Turano, P., Musiani, F., Neyroz, P., \& Ciurli, S. (2009). Zn2+-Linked Dimerization of Ureg from Helicobacter Pylori, a Chaperone Involved in Nickel Trafficking and Urease Activation. Proteins, 74(1), 222-239.

[52] Zambelli, B., Cremades, N., Neyroz, P., Turano, P., Uversky, V. N., \& Ciurli, S. (2012). Insights in the (Un)Structural Organization of Bacillus Pasteurii Ureg, an Intrinsically Disordered Gtpase Enzyme. Molecular BioSystems, 8(1), 220-228.

[53] Real-Guerra, R., Staniscuaski, F., Zambelli, B., Musiani, F., Ciurli, S., \& Carlini, C. R. (2012). Biochemical and Structural Studies on Native and Recombinant Glycine Max Ureg: A Detailed Characterization of a Plant Urease Accessory Protein. Plant Molecular Biology, 78(4-5), 461-475.

[54] Soriano, A., \& Hausinger, R. P. (1999). Gtp-Dependent Activation of Urease Apoprotein in Complex with the Ured, Uref, and Ureg Accessory Proteins. Proceedings of the National Academy of Sciences of the United States of America, 96(20), 11140-11144.

[55] Witte, C. P., Rosso, M. G., \& Romeis, T. (2005). Identification of Three Urease Accessory Proteins That Are Required for Urease Activation in Arabidopsis. Plant Physiolo$g y, 139(3), 1155-1162$.

[56] Cao, F. Q., Werner, A. K., Dahncke, K., Romeis, T., Liu, L. H., \& Witte, C.P. (2010). Identification and Characterization of Proteins Involved in Rice Urea and Arginine Catabolism. Plant Physiology, 154(1), 98-108.

[57] Hirayama, C., Sugimura, M., Saito, H., \& Nakamura, M. (2000). Purification and Properties of Urease from the Leaf of Mulberry, Morus Alba. Phytochemistry, 53(3), 325-330.

[58] Krishna, B. L., Singh, A. N., Patra, S., \& Dubey, V. K. (2011). Purification, Characterization and Immobilization of Urease from Momordica Charantia Seeds. Process Biochemistry, 46-1486.

[59] Lee, M. H., Mulrooney, S. B., Renner, MJ, Markowicz, Y., \& Hausinger, R. P. (1992). Klebsiella Aerogenes Urease Gene Cluster: Sequence of Ured and Demonstration 
That Four Accessory Genes (Ured, Uree, Uref, and Ureg) Are Involved in Nickel Metallocenter Biosynthesis. Journal of Bacteriology, 174(13), 4324-4330.

[60] Park, I. S., Carr, M. B., \& Hausinger, R. P. (1994). In Vitro Activation of Urease Apoprotein and Role of Ured as a Chaperone Required for Nickel Metallocenter Assembly. Proceedings of the National Academy of Sciences of the United States of America, 91(8), 3233-3237.

[61] Witte, C. P., Isidore, E., Tiller, S. A., Davies, H. V., \& Taylor, M. A. (2001). Functional Characterisation of Urease Accessory Protein G (Ureg) from Potato. Plant Molecular Biology, 45(2), 169-179.

[62] Vitousek, P. M., \& Howarth, R. W. (1991). Nitrogen Limitation on Land and in the Sea- How Can It Occur. Biogeochemistry, 13(2), 87-115.

[63] Elser, J. J., Fagan, W. F., Subramanian, S., \& Kumar, S. (2006). Signatures of Ecological Resource Availability in the Animal and Plant Proteomes. Molecular Biology and Evolution, 23(10), 1946-1951.

[64] Polacco, J. C., \& Holland, M. A. (1994). Genetic Control of Plant Ureases. Genetic engineering; principles and methods, 16-33.

[65] Sirko, A., \& Brodzik, R. (2000). Plant Ureases: Roles and Regulation. Acta Biochimica Polonica, 47(4), 1189-1195.

[66] Lam, H. M., Coschigano, K. T., Oliveira, I. C., Melo, Oliveira. R., \& Coruzzi, G. M. (1996). The Molecular-Genetics of Nitrogen Assimilation into Amino Acids in Higher Plants. Annual Review of Plant Physiology and Plant Molecular Biology, 47, 569-593.

[67] Witte, C. P., \& Medina-Escobar, N. (2001). In-Gel Detection of Urease with Nitroblue Tetrazolium and Quantification of the Enzyme from Different Crop Plants Using the Indophenol Reaction. Analytical Biochemistry, 290(1), 102-107.

[68] Liu, L. H., Ludewig, U., Frommer, W. B., \& von, Wiren. N. (2003). Atdur3 Encodes a New Type of High-Affinity Urea/H+ Symporter in Arabidopsis. The Plant Cell, 15(3), 790-800.

[69] Food and Agriculture Organization of the United States. (2011). Faostat. http:// faostat.fao.org.

[70] Stebbins, N. E., \& Polacco, J. C. (1995). Urease Is Not Essential for Ureide Degradation in Soybean. Plant Physiology, 109(1), 169-175.

[71] Witte, C. P., Tiller, S. A., Taylor, M. A., \& Davies, H. V. (2002). Leaf Urea Metabolism in Potato. Urease Activity Profile and Patterns of Recovery and Distribution of (15)N after Foliar Urea Application in Wild-Type and Urease-Antisense Transgenics. Plant Physiology, 128(3), 1129-1136.

[72] Polacco, J. C., \& Sparks, R. B. (1982). Patterns of Urease Synthesis in Developing Soybeans. Plant Physiology, 70(1), 189-194. 
[73] Carlini, C. R., \& Polacco, J. C. (2008). Toxic Properties of Urease. Crop Science, 48(5), 1665-1672.

[74] Carlini, C. R., Oliveira, A. E., Azambuja, P., Xavier-Filho, J., \& Wells, MA. (1997). Biological Effects of Canatoxin in Different Insect Models: Evidence for a Proteolytic Activation of the Toxin by Insect Cathepsinlike Enzymes. Journal of Economic Entomology, 90(2), 340-348.

[75] Follmer, C., Real-Guerra, R., Wasserman, G. E., Olivera-Severo, D., \& Carlini, C. R. (2004). Jackbean, Soybean and Bacillus Pasteurii Ureases. Biological Effects Unrelated to Ureolytic Activity. European Journal of Biochemistry , 271(7), 1357-1363.

[76] Staniscuaski, F., Ferreira-Dasilva, C. T., Mulinari, F., Pires-Alves, M., \& Carlini, C. R. (2005). Insecticidal Effects of Canatoxin on the Cotton Stainer Bug Dysdercus Peruvianus (Hemiptera: Pyrrhocoridae). Toxicon, 45(6), 753-760.

[77] Defferrari, M. S., Demartini, D. R., Marcelino, T. B., Pinto, P. M., \& Carlini, C. R. (2011). Insecticidal Effect of Canavalia Ensiformis Major Urease on Nymphs of the Milkweed Bug Oncopeltus Fasciatus and Characterization of Digestive Peptidases. Insect Biochemistry and Molecular Biology, 41(6), 388-399.

[78] Oliveira, A. E. A., Gomes, V. M., Sales, M. P., Fernandes, K. V. S., Carlini, C. R., \& Xavier-Filho, J. (1999). The Toxicity of Jack Bean [Canavalia Ensiformis (L.) Dc.] Canatoxin to Plant Pathogenic Fungi. Revista Brasileira de Biologia, 59(1), 59-62.

[79] Becker-Ritt, A. B., Martinelli, A. H., Mitidieri, S., Feder, V., Wassermann, G. E., Santi, L., Vainstein, M. H., Oliveira, J. T., Fiuza, L. M., Pasquali, G., \& Carlini, C. R. (2007). Antifungal Activity of Plant and Bacterial Ureases. Toxicon, 50(7), 971-983.

[80] Ghazaleh, F. A., Francischetti, I. M. B., Gombarovits, M. E. C., \& Carlini, C. R. (1997). Stimulation of Calcium Influx and Platelet Activation by Canatoxin: Methoxyverapamil Inhibition and Downregulation by Cgmp. Archives of Biochemistry and Biophysics, 339(2), 362-367.

[81] Carlini, C. R., \& Grossi-de-Sa, M. F. (2002). Plant Toxic Proteins with Insecticidal Properties. A Review on Their Potentialities as Bioinsecticides. Toxicon, 40(11), 1515-1539.

[82] Piovesan, A. R., Staniscuaski, F., Marco-Salvadori, J., Real-Guerra, R., Defferrari, M. S., \& Carlini, C. R. (2008). Stage-Specific Gut Proteinases of the Cotton Stainer Bug Dysdercus Peruvianus: Role in the Release of Entomotoxic Peptides from Canavalia Ensiformis Urease. Insect Biochemistry and Molecular Biology, 38(11), 1023-1032.

[83] Staniscuaski, F., Te, Brugge. V., Carlini, C. R., \& Orchard, I. (2010). Jack Bean Urease Alters Serotonin-Induced Effects on Rhodnius Prolixus Anterior Midgut. Journal of Insect Physiology, 56(9), 1078-1086.

[84] Menegassi, A., Wassermann, G. E., Olivera-Severo, D., Becker-Ritt, A. B., Martinelli, A. H., Feder, V., \& Carlini, C. R. (2008). Urease from Cotton (Gossypium Hirsutum) 
Seeds: Isolation, Physicochemical Characterization, and Antifungal Properties of the Protein. Journal of Agriculture and Food Science, 56(12), 4399-4405.

[85] Carlini, C. R., Guimaraes, J. A., \& Ribeiro, J. M. (1985). Platelet Release Reaction and Aggregation Induced by Canatoxin, a Convulsant Protein: Evidence for the Involvement of the Platelet Lipoxygenase Pathway. British Journal of Pharmacology, 84(2), 551-560.

[86] Barja-Fidalgo, C., Guimaraes, J. A., \& Carlini, C. R. (1991). Lipoxygenase-Mediated Secretory Effect of Canatoxin the Toxic Protein from Canavalia Ensiformis Seeds. Toxicon, 29(4-5), 453-459.

[87] Barja-Fidalgo, C., Guimaraes, J. A., \& Carlini, C. R. (1991). Canatoxin, a Plant Protein, Induces Insulin Release from Isolated Pancreatic Islets. Endocrinology, 128(2), 675-679.

[88] Grassi-Kassisse, D. M., \& Ribeiro-Da, Silva. G. (1992). Canatoxin Triggers Histamine Secretion from Rat Peritoneal Mast Cells. Agents Actions, 37(3-4), 204-209.

[89] Ferreira-Da, Silva. C. T., Gombarovits, ME, Masuda, H., Oliveira, C. M., \& Carlini, C. R. (2000). Proteolytic Activation of Canatoxin, a Plant Toxic Protein, by Insect Cathepsin-Like Enzymes. Archives of Insect Biochemistry and Physiology, 44(4), 162-171.

[90] Mulinari, F., Staniscuaski, F., Bertholdo-Vargas, L. R., Postal, M., Oliveira-Neto, O. B., Rigden, D. J., Grossi-de-Sa, M. F., \& Carlini, C. R. (2007). Jaburetox-2ec: An Insecticidal Peptide Derived from an Isoform of Urease from the Plant Canavalia Ensiformis. Peptides, 28(10), 2042-2050.

[91] Staniscuaski, F., Brugge, V. T., Carlini, C. R., \& Orchard, I. (2009). In Vitro Effect of Canavalia Ensiformis Urease and the Derived Peptide Jaburetox-2ec on Rhodnius Prolixus Malpighian Tubules. Journal of Insect Physiology, 55(3), 255-263.

[92] Staniscuaski, F., \& Carlini, C. R. (2012). Plant Ureases and Related Peptides: Understanding Their Entomotoxic Properties. Toxins Basel, 4(2), 55-67.

[93] Wiebke-Strohm, B., Pasquali, G., Margis-Pinheiro, M., Bencke, M., Buecker-Neto, L., Becker-Ritt, A. B., Martinelli, A. H. S., Rechenmacher, C., Polacco, J. C., Stolf, R., Marcelino, F. C., Abdelnoor, R. V., Homrich Del, M.S, Ponte, . E. M., Carlini, C. R., De Carvalho, M. C. C. G., \& Bodanese-Zanettini, M. H. (2012). Ubiquitous Urease Affects Soybean Susceptibility to Fungi. Plant Molecular Biology, 79(1-2), 75-87.

[94] Olivera-Severo, D., Wassermann, G. E., \& Carlini, C. R. (2006). Bacillus Pasteurii Urease Shares with Plant Ureases the Ability to Induce Aggregation of Blood Platelets. Archives of Biochemistry and Biophysics, 452(2), 149-155.

[95] Wassermann, G. E., Olivera-Severo, D., Uberti, A. F., \& Carlini, C. R. (2010). Helicobacter Pylori Urease Activates Blood Platelets through a Lipoxygenase-Mediated Pathway. Journal of Cellular and Molecular Medicine, 14(7), 2025-2034.

[96] American Soybean Association. Soystats. (2011). http://www.soystats.com/. 
[97] Cromwell, G. L. (1999). Soybean Meal- the "Gold Standard". The Farmer's Pride, 11(20).

[98] Liener, I. E. (1994). Implications of Antinutritional Components in Soybean Foods. Critical Reviews in Food Science and Nutrition, 34(1), 31-67.

[99] Gandhi, A. P., Nenwani, M. M., \& Ali, N. (1984). Investigations on the Trypsin-Inhibitor, Urease and Cooking Behavior of Soybean Glycine-Max Merr. Food Chemistry, 15(3), 215-218.

[100] Vasconcelos, I. M., Siebra, E. A., Maia, A. A. B., Moreira, R. A., Neto, A. F., Campelo, G. J. A., \& Oliveira, J. T. A. (1997). Composition, Toxic and Antinutritional Factors of Newly Developed Cultivars of Brazilian Soybean (Glycine Max). Journal of the Science of Food and Agriculture, 75(4), 419-426.

[101] Vasconcelos, I. M., Maia, A. A., Siebra, E. A., Oliveira, J. T., Carvalho, A. F., Melo, V. M., Carlini, C. R., \& Castelar, L. I. (2001). Nutritional Study of Two Brazilian Soybean (Glycine Max) Cultivars Differing in the Contents of Antinutritional and Toxic Proteins. The Journal of Nutritional Biochemistry, 12(1), 55-62.

[102] Becker-Ritt, A. B., Mulinari, F., Vasconcelos, I. M., \& Carlini, C. R. (2004). Antinutritional and/or Toxic Factors in Soybean (Glycine Max (L) Merril) Seeds: Comparison of Different Cultivars Adapted to the Southern Region of Brazil. Journal of the Science of Food and Agriculture, 84(3), 263-270.

[103] Food and Agriculture Organization of the United States. (2011). Fao. http:// www.fao.org/.

[104] Huntington, G. B., Harmon, D. L., Kristensen, N. B., Hanson, K. C., \& Spears, J. W. (2006). Effects of a Slow-Release Urea Source on Absorption of Ammonia and Endogenous Production of Urea by Cattle. Animal Feed Science and Technology, 130(3-4), 225-241.

[105] Symonds, H. W., Mather, D. L., \& Collis, K. A. (1981). The Maximum Capacity of the Liver of the Adult Dairy-Cow to Metabolize Ammonia. British Journal of Nutrition, 46(3), 481-486.

[106] Edwards, H. M. Jr. (1985). Effects of Different Soybean Meals on the Incidence of Tibial Dyschondroplasia in the Chicken. Journal of Nutrition, 115(8), 1005-1015.

[107] Veltmann, J. R., \& Jensen, L. S. (1981). Tibial Dyschondroplasia in Broilers- Comparison of Dietary Additives and Strains. Poultry Science, 60(7), 1473-1478.

[108] Edwards, H. M. (1984). Studies on the Etiology of Tibial Dyschondroplasia in Chickens. Journal of Nutrition, 114(6), 1001-1013.

[109] Qin, G., Elstter, E. R., Bosch, M. W., \& Poel vander, A. F. B. (1996). Thermal Processing of Whole Soya Beans: Studies on the Inactivation of Antinutritional Factors and Effects on Ileal Digestibility in Piglets. Animal Feed Science and Technology, 57(4), 313-324. 
[110] Quedraogo, C. L., Combe, E., Lalles, J. P., Toullec, R., Treche, S., \& Grongnet, J. F. (1999). Nutritional Value of the Proteins of Soybeans Roasted at a Small-Scale Unit Level in Africa as Assessed Using Growing Rats. Reproduction Nutrition Development, 39(2), 201-212.

[111] Vasconcelos, I. M., Brasil, I. C., Oliveira, J. T., Campello, C. C., Maia, F. M., Campello, M. V., Farias, D. F., \& Carvalho, A. F. (2009). Combination of Chemical Analyses and Animal Feeding Trials as Reliable Procedures to Assess the Safety of Heat Processed Soybean Seeds. Journal of Agriculture and Food Science, 57(11), 4668-4673.

[112] Caskey, C. D., \& Knapp, F. C. (1944). Method for Detecting Inadequately Heated Soybean Oil Meal. Industrial and Engineering Chemistry, 16(10), 640-641.

[113] Schramm, G., \& Aines, P. D. (1959). Colorimetric Determination of Urease Activity in Soybean Meals. Journal of the American Oil Chemists Society, 36(1), 1-3.

[114] Croston, C. B., Smith, A. K., \& Cowan, J. C. (1955). Measurement of Urease Activity in Soybean Oil Meal. Journal of the American Oil Chemists Society, 32(5), 279-282.

[115] Smith, A. K., Belter, P. A., \& Anderson, R. L. (1956). Urease Activity in Soybean Meal Products. Journal of the American Oil Chemists Society, 33(8), 360-363.

[116] Weatherburn, M. W. (1967). Phenol-Hypochlorite Reaction for Determination of Ammonia. Analytical Chemistry, 39(8), 971.

[117] Kaplan, A. (1969). The Determination of Urea, Ammonia, and Urease. Methods of Biochemical Analysis, 17, 311-324.

[118] Grossi-de-Sa, M. F., Pelegrini, P. B., \& Fragoso, R. R. (2011). Genetically Modified Soybean for Insect-Pests and Disease Control. In: Sudaric A (ed.) Soybean- Molecular Aspects of Breeding. Rijeka: InTech, 429-452.

[119] Oerke, E. C., \& Dehne, H. W. (2004). Safeguarding Production- Losses in Major Crops and the Role of Crop Protection. Crop Protection, 23(4), 275-285.

[120] Polacco, J. C. (1976). Nitrogen Metabolism in Soybean Tissue Culture: I. Assimilation of Urea. Plant Physiology, 58(3), 350-357.

[121] George, A. A., \& Delumen, B. O. (1991). A Novel Methionine-Rich Protein in Soybean Seed-Identification, Amino-Acid-Composition, and N-Terminal Sequence. Journal of Agriculture and Food Science, 39(1), 224-227. 
